\title{
ANALISIS FAKTOR YANG MEMPENGARUHI TINGKAT FERTIUTAS DI DESA LAUT DENDANG KECAMATAN PERCUT SEI TUAN KABUPATEN DELI SERDANG
}

\author{
Mona Adria Wirda, Ainka Irfany, Desi Septiyani, Della Theresa S, \\ Jovin Sidabutar \\ Jurusan Pendidikan Geografi, Fakultas IImu Sosial \\ Universitas Negeri Medan \\ Jalan Willem Iskandar Pasar V Medan Estate, Medan, 20221, Indonesia \\ Email: ainkairf17@gmail.com
}

\begin{abstract}
Abstrak
Penelitian ini bertujuan untuk mengetahui pengaruh berbagai faktor baik pendapatan, usia wal menikah, yang mempengaruhi terhadap tingkat fertilitas di Desa Laut Dendang. Jenis penelitian yang digunakan adalah metode korelasional. Penelitian ini dilakukan di Desa Laut Dendang dengan jumlah populasi sebesar 17.333 jiwa. Sampel yang digunakan sebanyak 50 dan sampel ditentukan berdasarkan teknik purpossive sampling dengan karakteristik sampel yakni wanita pasangan usia subur (PUS) yang sudah memiliki anak. pengaruh dari berbagai faktor terhadap fertilitas dihitung dengan menggunakan rumus product moment pearson. Hasil penelitian menunjukkan baha (1) semakin besar penghasilan keluarga akan berpengaruh terhadap besarnya keluarga dan pola konsumsi (2) pendidikan wanita berperan dalam perubahan status, sikap dan pandangan hidup mereka di dalam masyarakat (3) saat seseorang menikah pada usia yang relatif lebih muda, maka masa subur atau reproduksi akan lebih panjang dalam ikatan perkawinan sehingga mempengaruhi peningkatan fertilitas (4) pengaruh status pekerjaan istri terhadap fertilitas yang dimana pada umumnya sangat peka dengankeadaan dan permasalahan yang terjadi dalam keluarga (5) istri yang masih berumur muda akan terus memiliki anak karena mengganggap usianya masih aman untuk melahirkan (6) $K B$ menjadi salahsatu hal yang mempengaruhi fertilitas sebab dengan memakai $K B$ maka akan terjadi kehamilan yang terencana.
\end{abstract}

Kata kunci: Fertilitas, Pertumbuhan, Laut Dendang

\begin{abstract}
This study aims to determine the effect of various factors both income, age of marriage, which affect the level of fertility in the village of Laut Dendang. The type of research used is the correlational method. This research was conducted in Laut Dendang Village with a population of 17,333 people. The sample used was 50 and the sample was determined based on purposive sampling technique with sample characteristics, namely women of childbearing age (PUS) who already had children. the influence of various factors on fertility is calculated using the product moment person formula. The results show that (1) the greater family income will affect family size and consumption patterns (2) women's education plays a role in changing their status, attitudes and outlook on life in society (3) when a person marries at a relatively younger age, then the fertile or reproductive period will be longer in marital relations so that it affects the increase in fertility (4) the influence of wife's employment status on fertility which in general is very sensitive to the situation and problems that occur in the family (5) wives who are still young because assuming age is still safe for childbirth (6) family planning is one of the things that affect fertility because by using family planning, a planned pregnancy will occur.
\end{abstract}

Keywords: Fertility, Growth, Laut Dendang 


\section{PENDAHULUAN}

Fertilitas merupakan jumlah dari anak yang dilahirkan hidup dengan pengertian bahwa anak yang pernah dilahirkan dalam kondisi hidup menunjukkan tanda-tanda kehidupan. Jika anak pada saat dilahirkan dalam kondisi hidup kemudian meninggal pada waktu masih bayi tetap dikatakan Anak Lahir Hidup (ALH) (Sukarno, 2010)

Besar kecilnya jumlah kelahiran dalam suatu penduduk, tergantung pada beberapa faktor misalnya struktur umur, tingkat pendidikan, umur pada waktu kawin pertama, banyaknya perkawinan, status pekerjaan wanita, penggunaan alat kontrasepsi dan pendapatan atau kekayaan (Hatmadji, 2004).

Kepadatan penduduk dipengaruhi oleh fertilitas atau kelahiran hidup, sedangkan faktor-faktor yang mempengaruhi tinggi rendahnya tingkat fertilitas adanya perbedaan tingkat sosial ekonomi masyarakat seperti tingkat pendapatan keluarga, pendidikan keluarga, usia kawin pertama dan lama penggunaan kontrasepsi (Mantra 2012:167)

Menurut Mantra, (2012) Faktor yang Mempengaruhi Fertilitas adalah Pendidikan Istri, Usia Kawin Pertama Istri, Status bekerja istri, pendapatan keluarga, dan penggunaan alat kontrasepsi oleh istri. Pendidikan dianggap sebagai input dan output perubahan demografi, pendidikan yang tinggi seringkali mendorong kesadaran orang untuk tidak memiliki banyak anak. "New household economics" berpendapat bahwa bila pendapatan ibu dan pendidikan meningkat maka semakin banyak waktu (khususnya waktu ibu) yang digunakan untuk merawat anak. Menurut (Mudiharno, 2007) anak menjadi lebih mahal. Sehingga hal ini dapat mengurangi angka kelahiran. Semakin tinggi pendidikan semakin rendah kesuburan yang mengakibatkan penurunan pada fertilitas. Dengan pendidikan yang tinggi seseorang cendrung memilih untuk mempunyai anak dalam jumlah kecil tetapi bermutu, dibanding dengan memiliki banyak anak tetapi tidak terurus. Disisi lain fertilitas juga memberi kesempatan kepada pemerintah dan para orang tua untuk lebih memperhatikan anak.

Usia kawin pertama dalam suatu pernikahan berarti umur memulai berhubungan kelamin antar individu wanita yang terkait dalam suatu lembaga perkawinan dalam berbagai ketentuan mengenai hak dan kewajiban dari masingmasing individu (Iswarati, 2009).

Usia perkawinan dalam suatu pernikahan berarti umur terjadinya hubungan kelamin antara individu pria dan wanita yang terikat dalam suatu lembaga perkawinan dengan berbagai ketentuan mengenai hak dan kewajiban dari masingmasing individu. Pada masyarakat yang sedang berkembang, usia perkawinan pertama cenderung muda sehingga nilai fertilitasnya tinggi. Dengan kata lain semakin cepat usia kawin pertama, semakin besar kemungkinan mempunyai anak (Singarimbun, 2008).

Status ketenagakerjaan ibu mempunyai pengaruh terhadap tingkat fertilitas karena ibu yang bekerja umumnya mempunyai tingkat fertilitas lebih rendah dari ibu yang tidak bekerja. Status ketenagakerjaan merupakan proses penciptaan atau pembentukan nilai-nilai baru pada unit sumberdaya dan pengubahan atau penambahan nilai pada unit pemenuhan kebutuhan yang ada.

Status bekerja maupun tidak akan memengaruhi wanita dalam penetapan usia pernikahannya. Jika kesempatan kerja di suatu wilayah itu besar, maka wanita akan memilih untuk menunda pernikahan demi mengejar karir.

Pendapatan adalah faktor yang paling dominan dalam mempengaruhi suatu keputusan seseorang atau keluarga dalam merencanakan jumlah anak. Hubungan antara fertilitas dengan penghasilan keluarga menurut Hull dalam Singarimbun (2008) menyatakan bahwa wanita dalam kelompok berpenghasilan rendah akan cenderung mengakhiri masa reproduksinya lebih awal dibandingkan dengan wanita pada kelompok berpenghasilan sedang dan tinggi. Timbulnya perbedaan tersebut menyebabkan fertilitas wanita berpenghasilan tinggi naik lebih cepat dibandingkan dengan wanita berpenghasilan rendah. Semakin besar penghasilan keluarga akan berpengaruh terhadap besarnya keluarga dan pola konsumsi karena terdorong oleh tersedianya barang produk baru sehingga dampak dari pembangunan ekonomi juga akan merubah pandangan tentang jumlah anak yang dilahirkan. Kenaikan pendapatan akan menyebabkan harapan orang tua untuk berubah.

Lama penggunaan alat kontrasepsi inilah yang menyebabkan terjadinya penurunan 
fertilitas. Menurut Saleh (2003:62) selain itu ada perbedaan yang mencolok yang semakin tinggi pendidikan yang ditamatkan oleh seorang wanita semakin besar kecenderungan wanita tersebut untuk menggunakan alat kontrasepsi.

\section{METODE PENELITIAN}

Penelitian ini dilakukan di Desa Laut Dendang Kecamatan Percut Sei Tuan Kabupaten Deli Serdang. Alasan peneliti memilih lokasi tersebut karena pada faktanya daerah ini mempunyai jumlah kelahiran bayi yang tergolong tinggi dibandingkan dengan desa atau kelurahan lainnya yang berada di satu kecamatan yang sama. Penelitian ini didesain dalam bentuk penelitian kuantitatif korelasional. Jenis penelitian ini menggunakan metode korelasional. pengambilan sampel penelitian ini mengunakan teknik Purposive Sampling yaitu teknik penentuan sampel dengan pertimbangan tertentu danberdasarkankarakteristik-karakteristik sesuai dengan tujuan penelitian. Pengaruh dari berbagai faktor terhadap fertilitas dihitung dengan menggunakan rumus Product Moment Pearson. Peneliti menentukan jumlah sampel sebanyak 50 wanita pasangan usia subur (PUS). Jumlah tersebut dianggap cukup mewakili dalam penelitian dan dapat di pertanggung jawabkan secara ilmiah.

Tabel 1. Kriteria Fertilitas

\begin{tabular}{ccc}
\hline No. & Tingkat & Kriteria \\
\hline 1. & Rendah & 1 \\
2. & Ideal & 2 \\
3. & Banyak & $>2$ \\
\hline & Sumber: BKKBN & 2015
\end{tabular}

Tabel 2. Tingkat Pendapatan

\begin{tabular}{cc}
\hline Kriteria & Tingkat \\
\hline$<2,7 \mathrm{Jt}$ & Dibawah UMK \\
$>2,7 \mathrm{Jt}$ & Diatas UMK \\
\hline Sumber: UMK Deli Serdang 2018
\end{tabular}

Sumber: UMK Deli Serdang, 2018

Tabel 3. Tingkat Pendidikan

\begin{tabular}{|c|c|}
\hline Jenjang Pendidikan & Kelas \\
\hline SD & 1 \\
\hline$S M P$ & 2 \\
\hline SMA & 3 \\
\hline PT & 4 \\
\hline \multicolumn{2}{|c|}{ Tabel 4. Usia Nikah Pertama } \\
\hline Kelas & Usia \\
\hline Muda & 20 \\
\hline Ideal & 21 \\
\hline Tua & $>30$ \\
\hline \multicolumn{2}{|c|}{ Sumber: UU No 1, 1974} \\
\hline \multicolumn{2}{|c|}{ Tabel 5. Status Pekerjaan } \\
\hline Status & Kelas \\
\hline Tidak Bekerja & 1 \\
\hline Bekerja & 2 \\
\hline
\end{tabular}

Tabel 6. Permintaan Anak Pada Wanita PUS

\begin{tabular}{lcc}
\hline No. & Kelas & Jumlah Permintaan \\
\hline 1. & Rendah & 1 \\
2. & Ideal & 2 \\
3. & Banyak & 3 \\
\hline
\end{tabular}

Sumber: BKKBN, 2015 


\section{HASIL DAN PEMBAHASAN}

Desa Laut Dendang terletak di Kecamatan Percut Sei Tuan Kabupaten Deli Serdang. Letak geografis desa Desa Laut Dendang adalah $3^{\circ} 62^{\prime} L U-98^{\circ} 72^{\prime} B T$. Desa ini terletak pada pinggiran kota Medan, artinya secara urusan administrai lebih dekat ke kota Medan, namun karena wilayah Desa Laut Dendang ini berada di bawah pemerintahan Kabupaten Deli Serdang maka segala urusan surat menyurat diwajibkan ke Lubuk Pakam sebagai ibu kota Kabupaten Deli Serdang. Desa Laut Dendang memiliki suhu yang tergolong panas, yakni rata-rata suhu di Desa Laut Dendang berkisar $29-34^{\circ} \mathrm{C}$.

Penduduk Desa Laut Dendang berjumlah 17.333 jiwa, dengan jumlah penduduk lakilaki sebanyak 8.790 jiwa, dan penduduk perempuan sebanyak 8.543 jiwa. Adapun tingkat kepadatan penduduk adalah 10.196 jiwa $/ \mathrm{km}^{2}$. (Data Statistik Desa Laut Dendang tahun 2016). Dari data tersebut dapat diketahui bahwa jumlah penduduk Desa Laut Dendang terhitung cukup padat, hal ini mungkin disebabkan karena Desa Laut Dendang merupakan desa alternatif bagi penduduk sekitar Medan untuk mendirikan bangunan atau untuk menetap dikarenakan desa ini yang letaknya tidak begitu jauh dari kota Medan dan harga tanah yang relatif masih terjangkau oleh masyarakat.

Dari data tersebut didapat informasi bahwa jumlah laki-laki lebih banyak dibandingkan dengan jumlah perempuan. Tingkat usia penduduk dapat dipahami produktivitasnya jika diketahui keadaan pendidikan mereka. Keadaan pendidikan tersebut dapat dilihat melalui tabel berikut:

Tabel 7. Keadaan Penduduk Menurut Pendidikan

\begin{tabular}{clc}
\hline No. & \multicolumn{1}{c}{ Tingkat Pendidikan } & Jumlah \\
\hline 1 & 3-6 tahun yang belum TK & 45 \\
2 & 3-6 tahun yang sedang TK & 187 \\
3 & 7-18 yang tidak pernah sekolah & - \\
4 & 7-18 yang sedang sekolah & 3120 \\
5 & 18-56 yang tidak pernah sekolah & - \\
6 & 18-56 pernah SD tetapi tidak tamat & 40 \\
7 & Tamat SD / Sederajat & 3254 \\
8 & 18-56 tidak tamat SMP & 53 \\
9 & Tamat SMP / Sederajat & 3515 \\
10 & Tamat SMA / Sederajat & 3286 \\
11 & Tamat DI / Sederajat & 27 \\
12 & Tamat DII / Sederajat & 24 \\
13 & Tamat DIII / Sederajat & 3302 \\
14 & Tamat S1 / Sederajat & 321 \\
15 & Tamat S2 / Sederajat & 54 \\
16 & Tamat S3 / Sederajat & 40 \\
17 & Tamat SLB C & 65 \\
\hline
\end{tabular}

Sumber: Desa Laut Dendang2016

Dari tabel diatas terlihat bahwa dari segi pendidikan masyarakat Desa Laut Dendang tergolong masyarakat berpendidikan, bahkan yang berpendidikan \$2 dan S3 cukup banyak dan hal ini dimungkinkan karena sebagian dosen-dosen UNIMED dan UIN SU bertempat tinggal di Desa Laut
Dendang karena jarak desa ini dengan kedua kampus tersebut cukup dekat. Tingkat pendidikan penduduk tentunya akan mempengaruhi lapangan pekerjaan. Hal ini dapat dilihat melalui tabel dibawah ini:

Tabel 8. Keadaan Penduduk Menurut Pekerjaan

\begin{tabular}{|c|c|c|}
\hline No. & Jenis Pekerjaan & Jumlah \\
\hline 1. & Buruh & 35 \\
\hline 2. & Buruh Tani & 4 \\
\hline 3. & PNS & 287 \\
\hline 4. & Perajin & 10 \\
\hline 5. & Pedagang Keliling & 15 \\
\hline 6. & Peternak & 18 \\
\hline 7. & Montir & 13 \\
\hline 8. & Tenaga Kesehatan & 44 \\
\hline 9. & TNI & 53 \\
\hline 10. & Polri & 65 \\
\hline 11. & Pensiunan PNS/Polri/TNI & 63 \\
\hline 12. & Pengusaha kecil dan menengah & 365 \\
\hline 13. & Pengacara & 18 \\
\hline 14. & Notaris & 3 \\
\hline 15. & Dukun kampung & 2 \\
\hline 16. & Jasa pengobatan alternatif & 8 \\
\hline 17. & Dosen swasta & 13 \\
\hline 18. & Petani & 2450 \\
\hline \multirow[t]{2}{*}{19.} & Pedagang & 154 \\
\hline & JUMLAH & 3466 \\
\hline
\end{tabular}

Sumber: Desa Laut Dendang 2016 
Dari tabel diatas terlihat pekerjaan yang paling banyak dilakukan olehmasyarakat Desa Laut Dendang adalah Petani kemudian disusul oleh Pengusaha Kecil dan Menangah kemudian PNS.

Kondisi social ekonomi masyarakat sebenarnya tergolong baik. Kondisi ini dapat dilihat dari data pekerjaan penduduk. Namun perlu menjadi perhatian bahwa tingkat perkembangan sosial ekonomi belum merata. Masih terlihat adanya unsur kesenjangan antara kehidupan kelas menengah dengan masyarakat bawah. Inilah yang belakangan ini diupayakan oleh berbagai aparat yang terkait.

Agama sedikit banyaknya mempengaruhi budaya dan etos kerja masyarakat. Pengaruh yang timbul dapat terjadi secara langsung atau tidak langsung. Menurut sumber data KUA Kecamatan Percut Sei Tuan bahwasanya masyarakat Desa Laut Dendang mayoritas memeluk agama islam, dan mereka ini sebagian besar adalah suku Jawa.

Adapun kegiatan keagamaan masyarakat di desa ini sama seperti yang sering dijumpai di daerah lain, dimana masyarakat selalu mengadakan pengajian dikhususkan kepada pengajian remaja dibawah naungan remaja Masjid. Kemudian pengajian kaum ibu-ibu serta pengajian bapak-bapak.

Perkembangan etos kerja masyarakat di desa ini dipengaruhi juga oleh sikap rasional dan kebiasaan yang dikerjakan oleh orangtua atau nenek-nenek mereka, dari sini dapat dikatakan bahwa kondisi semangat kerja masyarakat secara umum dapat dikatakan relatif baik. Hal ini semakin jelas dengan semakin banyaknya orang yang terpelajar dari desa ini. Sehingga etos kerja masyarakat Desa Laut Dendang dapat digolongkan etos kerja yang kreatif, inovatif, dan optimis.

Budaya masyarakat Desa Laut Dendang ini memasuki budaya transional. Masyarakat transisi maksudnya adalah masyarakat yang berada dalam situasi budaya desa yang masih berpegang teguh pada budaya. Sedangkan disisi lain mereka mulai tersentuh oleh budaya modern yang bisa juga disebut budaya global.

\section{Jumlah Anak Responden}

Distribusi responden berdasarkan jumlah anak dalam rumah tangga, dapat dilihat pada gambar berikut:

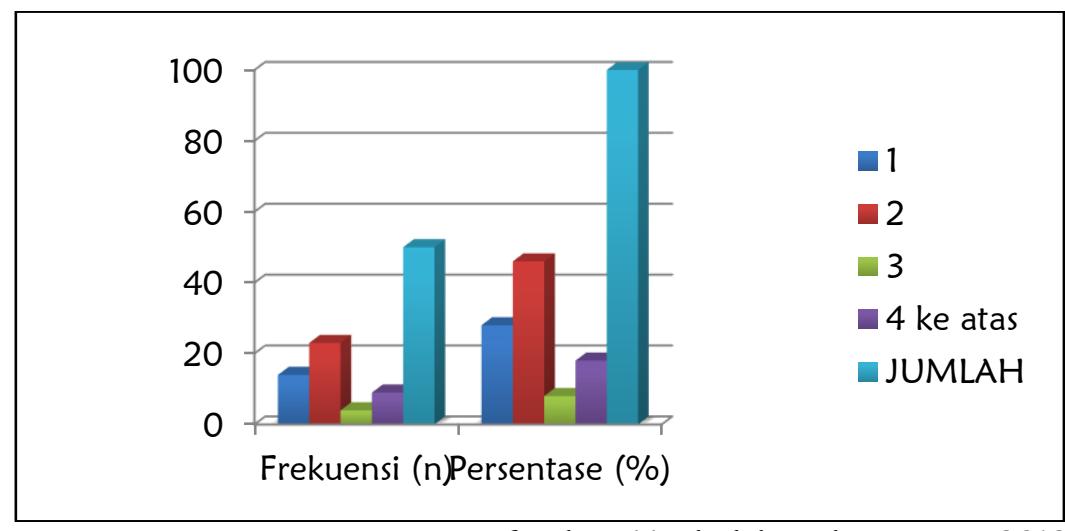

Sumber: Hasil olahan data primer 2018

Gambar 1. Distribusi Responden Berdasarkan Jumlah Anak Di Desa Laut Dendang 2018

Berdasarkan gambar 1 dapat dilihat bahwa jumlah anak yang di miliki responden sebanyak 2 memiliki persentase tertinggi yaitu sebesar $46 \%$ dan jumlah anak 1 memiliki persentase sebesar 28\% begitupun dengan yang memiliki anak 3 dengan persentase hanya $8 \%$ dan yang terakhir dengan jumlah anak lebih dari 4 ke atas memiliki persentase $18 \%$ hal ini di sebabkan karena memang banyak pasangan usia subur di Desa Laut Dendang yang usia pernikahannya masih 10-15 tahun atau kurang dari 5 tahun, sehingga masih memiliki 2 anak dan 1 anak. Selain itu alasan kuatnya adalah seseorang lebih memilih meningkatkan mutu anak dari pada memperbanyak anak. Kemudian ada beberapa responden yang memang memiliki banyak anak sebab mereka merasa bahwa punya anak sedikit itu tidak enak.

\section{Usia Kawin Pertama Istri}

Karakteristik responden berdasarkan umur awal nikah bertujuan untuk mengetahui umur wanita pada saat awal nikah. Umur perkawinan pertama wanita 
erat hubungannya dengan fertilitas. Pada masyarakat yang sedang berkembang, usia perkawinan pertama cenderung muda sehingga nilai fertilitasnya tinggi. Dengan kata lain semakin cepat usia kawin pertama, semakin besar kemungkinan mempunyai anak. Karena bila umur perkawinan pertamanya semakin muda semakin mendekati umur haid pertama kali, maka semakin cepat masa reproduksinya. Hal ini berarti semakin cepat seorang perempuan untuk fertilitas dan melahirkan, semakin tua usia kawin pertama seorang wanita, semakin tinggi pula resiko yang di hadapi dalam masa kehamilan atau melahirkan. Hal ini terjadi karena semakin lemahnya kondisi fisik seorang wanita menjelang usia menopouse.

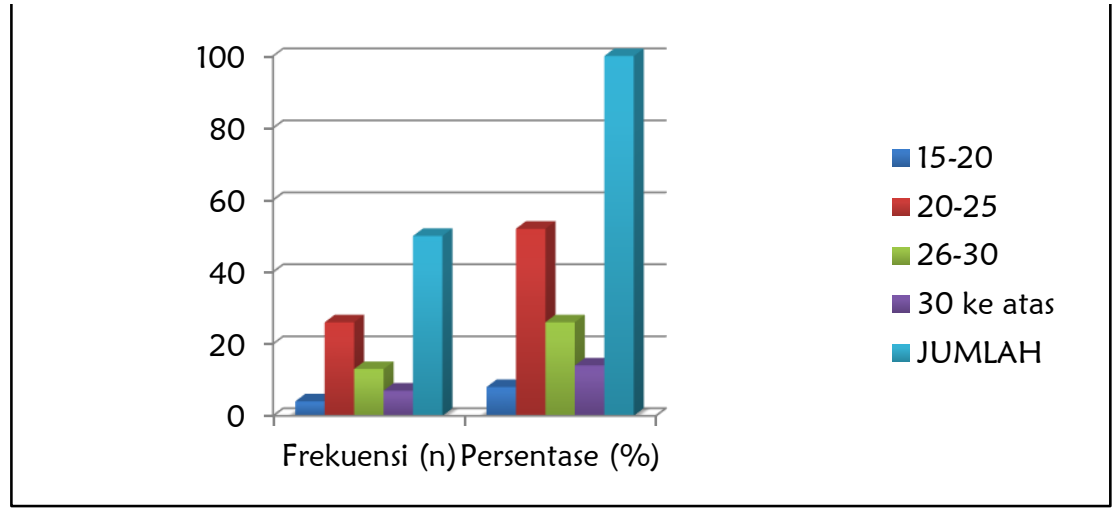

Sumber: Hasil olahan data primer 2018

Gambar 2. Distribusi Responden Berdasarkan Umur Kawin Pertama Istri Di Desa Laut Dendang 2018

Berdasarkan hasil penelitian (gambar 2) umur awal nikah 20-25 tahun dengan persentase $52 \%$ menduduki peringkat pertama, sementara untuk umur awal nikah di tahun 26-30 dengan persentase 26\% berada di peringkat kedua dan untuk peringkat terakhir di tempati oleh umur awal nikah 15-20 dengan persentase 8\%. Hal ini di sebabkan karena lebih banyak responden memilih untuk melanjutkan pendidikannya di tingkat SMA dan perguruan tinggi kemudian berkarir atau bekerja kemudian menikah kemudian dibandingkan dengan responden yang lebih cepat menikah.

\section{Usia Kawin Pertama Suami}

Distribusi responden berdasarkan usia perkawinan pertama suami di Desa Laut Dendang, dapat dilihat pada gambar berikut:

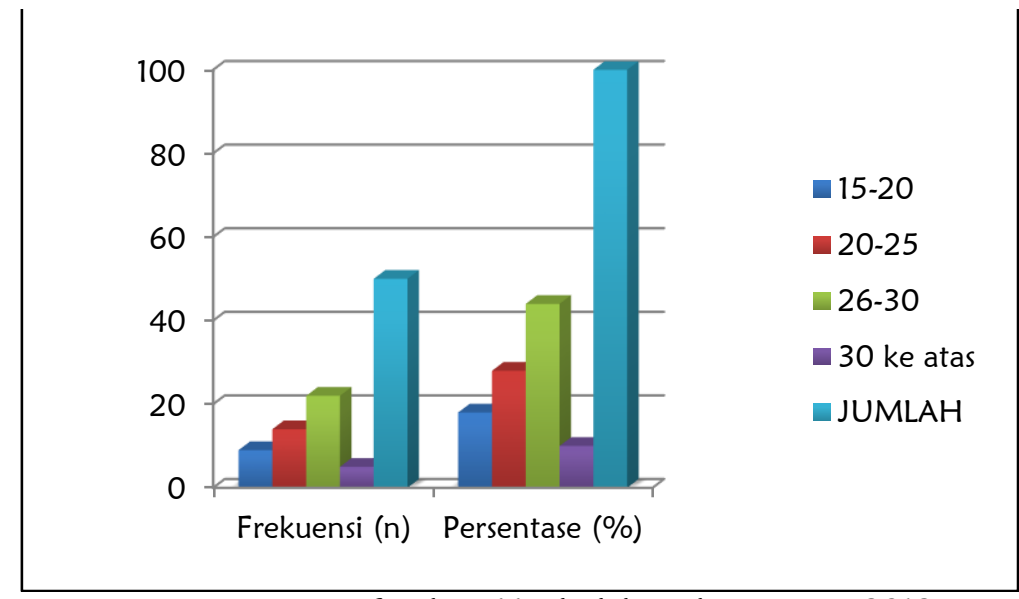

Sumber: Hasil olahan data primer 2018

Gambar 3. Distribusi Responden Berdasarkan Umur Kawin Pertama Suami Di Desa Laut Dendang 2018 
Umur suami berhubungan dengan fertilitas. Karena semakin banyak umur suami maka semakin besar rata-rata jumlah anak lahir hidup tiap keluarga. Berdasarkan hasil penelitian (gambar 3) umur awal nikah 26-30 tahun dengan persentase 44\% menduduki peringkat pertama, sementara untuk umur awal nikah di tahun 20-25 dengan persentase $28 \%$ berada di peringkat kedua dan untuk peringkat terakhir di tempati oleh awal umur nikah 30 tahun ke atas dengan persentase hanya 10\%. Dengan ini dapat dilihat bahwa rata-rata kawin pertama suami berumur 26-30 tahun.

\section{Pendidikan Istri}

Dari gambar 4 dapat di ketahui bahwa tingkat pendidikan yang di selesaikan oleh istri sangat bervariasi, dari tingkat pendidikan terakhir pada wanita pasangan usia subur di desa Laut Dendang, jumlah responden yang mempunyai pendidikan SMA/SMK di urutan pertama yakni sebesar $42 \%$, kemudian yang telah menyelesaikan pendidikan di perguruan tinggi sebesar $30 \%$, sedangkan yang paling kecil di susul oleh pendidikan SD yakni sebesar $6 \%$. Tingkat pendidikan perempuan di sebabkan oleh faktor budaya, sistem nilai/norma yang berlaku di masyarakat, agama, atau kekeliruan cara pandang perencanaan dan pengambilan keputusan terhadap peran dan status perempuan.

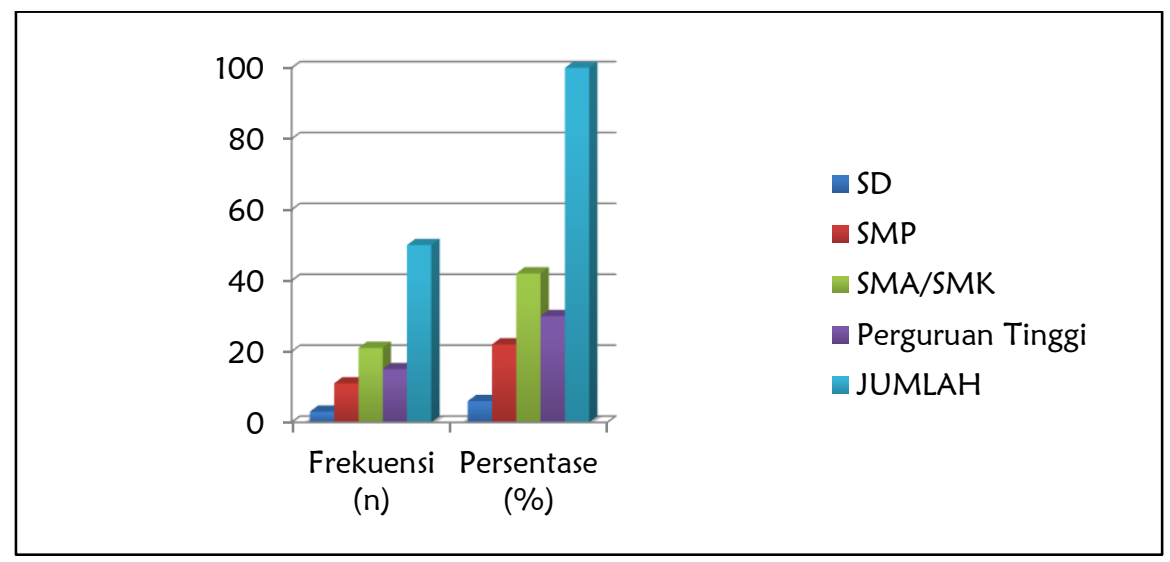

Sumber: Hasil olahan data primer 2018

Gambar 4. Distrubusi Responden Berdasarkan Pendidikan Istri Di Desa Laut Dendang 2018

\section{Pendidikan Suami}

Dilihat dari tingkat pendidikan terakhir pada suami di dalam rumah tangga pasangan usia subur di desa Laut Dendang maka jumlah responden terbesar adalah responden yang berpendidikan Perguruan
Tinggi dengan persentase 34\%, kemudian SMA/SMK sebesar $28 \%$ sedangkan yang paling kecil di susul oleh tingkat pendidikan SMP dengan persentase 18\%.

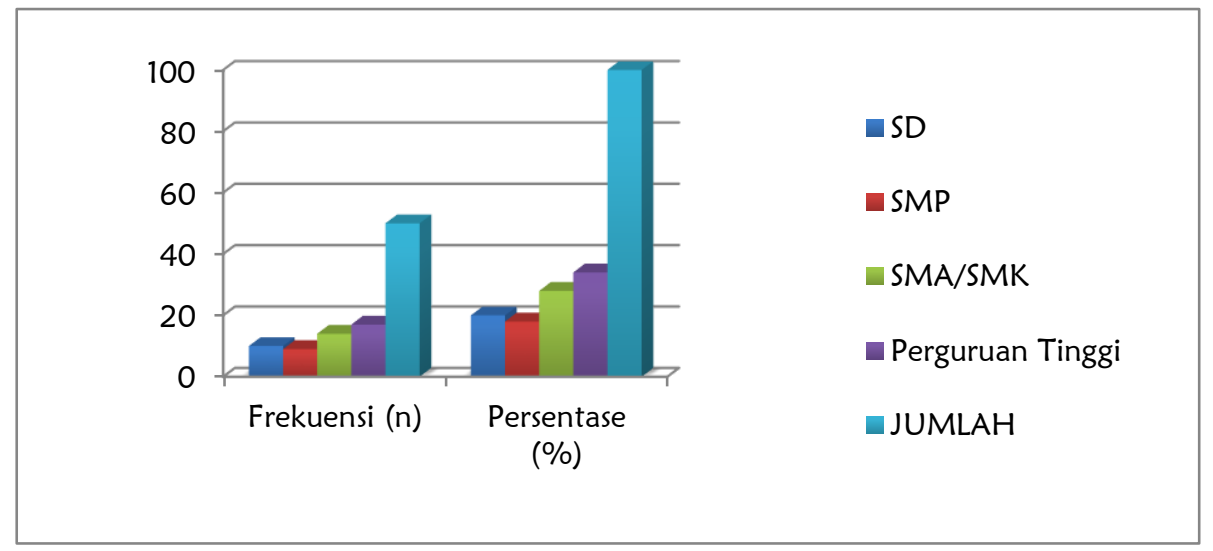

Sumber: olahan data primer 2018

Gambar 5. Distrubusi Responden Berdasarkan Pendidikan Suami Di Desa Laut Dendang 2018 


\section{Pendapatan Keluarga}

Pendapatan keluarga adalah penerimaan total tiap bulan dari suami dan istri maupun anggota keluarga yang lain. Pendapatan keluarga dari responden di peroleh dari pendapatan tetap dari suami maupun istri dari pekerjaan tetapnya. Di tambah dari pendapatan dari pekerjaan sampingan ataupun pendapatan dari anggota keluarga lain. Selain itu pendapatan juga dapat di peroleh dari ada tidaknya usaha keluarga yang di miliki oleh responden.

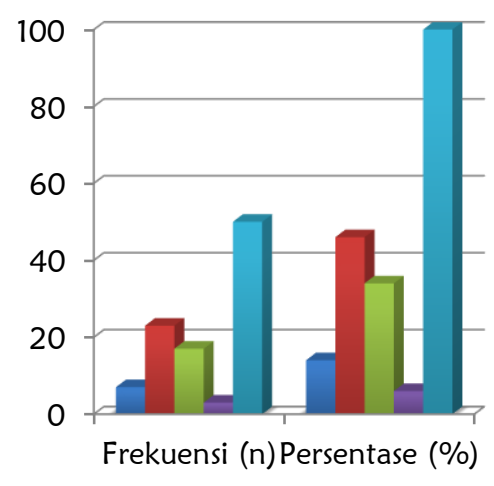

$<1.000 .000$

$1.100 .000-3.000 .000$

$3.100 .000-6.000 .000$

$>6.000 .0000$

JUMLAH

Sumber: olahan data primer 2018

Gambar 6. Distriubusi Responden Berdsarkan Pendapatan Keluarga Di Desa Laut Dendang

Gambar 6 di atas merupakan karakteristik responden berdasarkan pendapatan bertujuan untuk mengetahui seberapa besar jumlah pendapatan rsponden di Kecamatan Mariso Kota Makassar pada pasangan usia subur. Berdasarkan hasil penelitian menunjukkan bahwa sebanyak $14 \%$ responden mempunyai pendapatan di bawah 1.000.000, sementara untuk pendapatan 1.100.000-3.000.000 Rupiah sebesar 46\%, pendapatan dari 3.100.000-6.000.000 Rupiah sebanyak $34 \%$ dan hanya ada $6 \%$ untuk mereka yang berpendapatan di atas 6.000.000 rupiah.

Wanita dalam kelompok berpenghasilan rendah akan cenderung mengakhiri masa reproduksinya lebih awal dibandingkan dengan wanita pada kelompok berpenghasilan sedang dan tinggi. Timbulnya perbedaan tersebut menyebabkan fertilitas wanita berpenghasilan tinggi naik lebih cepat dibandingkan dengan wanita berpenghasilan rendah. Semakin besar penghasilan keluarga akan berpengaruh terhadap besarnya keluarga dan pola konsumsi karena terdorong oleh tersedianya barang produk baru sehingga dampak dari pembangunan ekonomi juga akan merubah pandangan tentang jumlah anak yang dilahirkan.

\section{Status pekerjaan istri}

Gambar 7 karakteristik responden berdasarkan status pekerjaan istri bertujuan untuk mengetahui seberapa besar jumlah pendapatan responden dalam hal ini wanita pekerja pada pasangan usia subur Desa Laut Dendang. Berdasarkan hasil penelitian menunjukkan bahwa sebanyak 45,3\% responden mempunyai pekerjaan, sementara wanita yang tidak bekerja sebanyak 54,6\%. Hal ini menunjukkan bahwa lebih banyak wanita yang telah menikah tidak bekerja di Kecamatan Mariso Kota Makassar. 


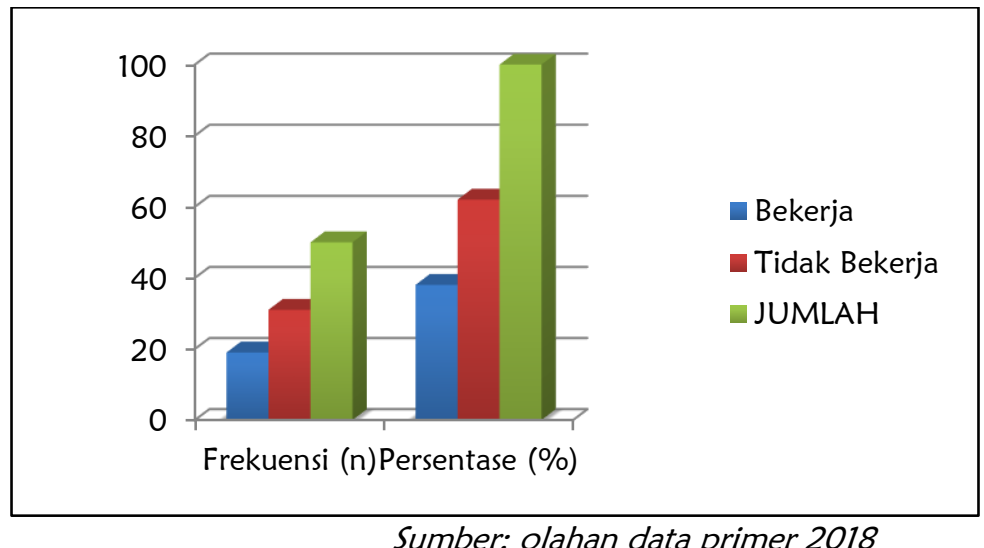

Gambar 7. Distribusi Responden Berdasarkan Status Pekerjaan Istri Di Desa Laut Dendang 2018

\section{Permintaan Anak Pada Wanita Pasangan Usia Subur}

Fertilitas adalah kemampuan alami untuk memberikan keturunan atau bisa di katakan kelahiran anak dalam keadaan hidup. Gambar 8 menunjukkan bahwa jumlah anak yang di harapkan oleh keluarga responden terendah adalah 1 dan yang tertinggi adalah $>3$ anak. Data tersebut memperlihatkan bahwa sebagian besar responden yaitu 26 responden atau $52 \%$ mengharapkan jumlah anak 2. Dan yang paling sedikit adalah responden yang menginginkan anak sebesar 1 atau $8 \%$.

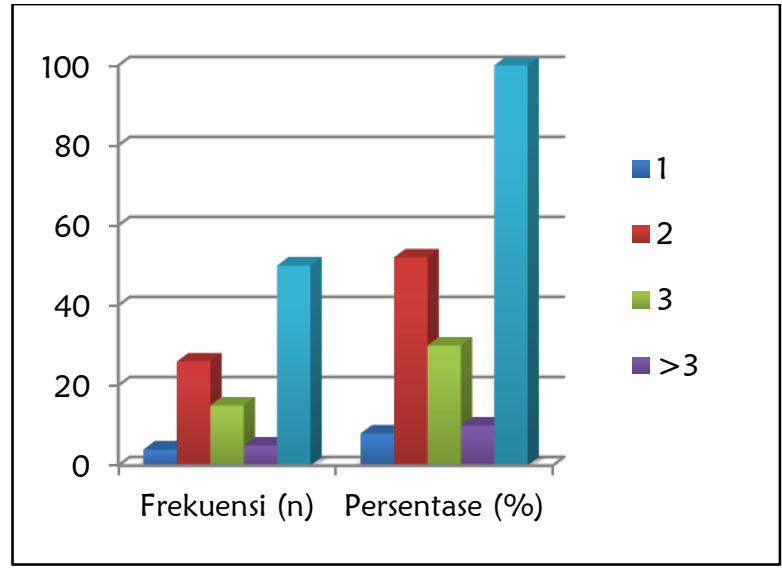

Sumber: Olahan data primer 2018

Gambar 8. Distribusi Responden Berdasarkan Permintaan Anak Pada Wanita PasanganUsia Subur Di Desa Laut Dendang 2018

\section{Penggunaan KB Pada Wanita Pasangan Usia Subur}

Berdasarkan hasil gambar 9. diperoleh informasi bahwa sebanyak 29 responden atau sebesar $58 \%$ sudah menggunakan KB. Kemudian yang tidak memakai KB sebanyak
21 responden yakni sebesar 42\%. Responden menjelaskan bahwa tidak memakai KB karena ingin jarak umur anak mereka tidak terlalu jauh sehingga dapat membesarkan anaknya sekaligus. 


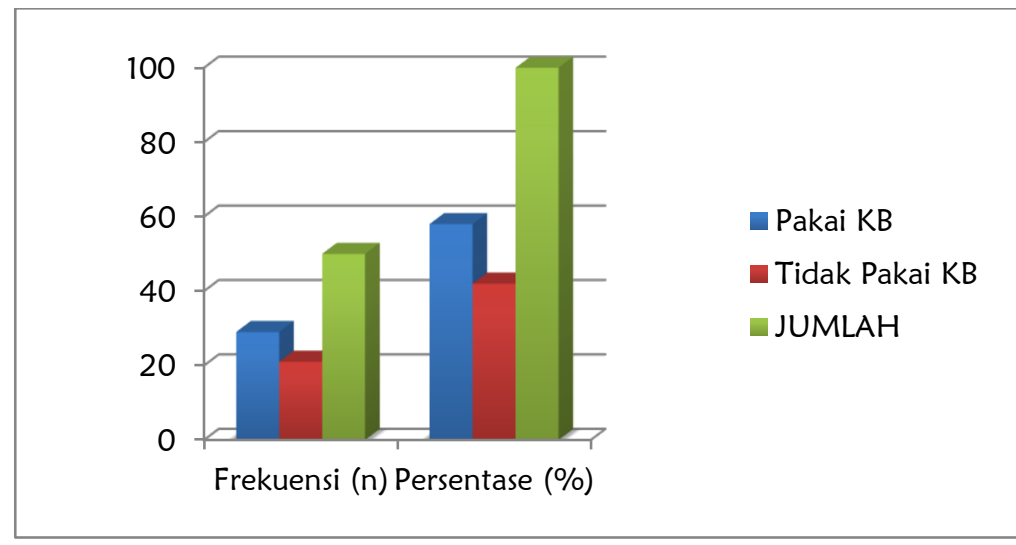

Sumber: olahan data primer 2018

Gambar 9. Distribusi Responden Berdasarkan Penggunaan KB Pada Wanita PasanganUsia Subur Di Desa Laut Dendang 2018

Tabel 9. Hasil Pengukuran Pengaruh Terhadap Berbagai Faktor Fertilitas

\begin{tabular}{llcl}
\hline No & \multicolumn{1}{c}{ Variabel } & $\begin{array}{c}\text { Koefisien } \\
\text { Regresi }\end{array}$ & \multicolumn{1}{l}{ Interpretasi } \\
\hline 1 & Pendidikan & 0 & $\begin{array}{l}\text { Sangat } \\
\text { Rendah }\end{array}$ \\
2 & Usia Nikah Pertama & -0.65092 & Kuat \\
3 & Permintaan Anak pada Wanita PUS & -0.63129 & Kuat \\
4 & Penggunaan KB & -0.43364 & Sedang \\
5 & Pendapatan & -0.08517 & Sangat Kuat \\
6 & Status Pekerjaan Istri & -0.05300 & Sedang \\
\hline
\end{tabular}

\section{Pengaruh Pendapatan Keluarga Terhadap Fertilitas}

Berdasarkan table 9. Dapat dilihat bahwa nilai koefisien regensi adalah 0.08517 (sangat tinggi) hal ini menunjukkan bahwa pendapatan adalah faktor yang paling dominan dalam mempengaruhi suatu keputusan seseorang atau keluarga dalam merencanakan jumlah anak. Keadaan ekonomi suatu keluarga sangat tergantung pada pendapatan keluarga itu sendiri. Orang tua menginginkan anak dengan kualitas baik, hal ini berarti akan meningkatkan biaya pengeluaran lebih banyak dan perubahan pada pendapatan keluarga tersebut dapat mempengaruhi fertilitas.

Apabila ada kenaikan pendapatan orang tua, maka aspirasi orang tua untuk mempunyai anak akan berubah. Orang tua menginginkan anak dengan kualitas yang lebih baik. Misalnya, dengan menyekolahkan anak setinggi mungkin, memberi makanan bergizi dengan jumlah yang cukup, memberikan kursus-kursus di luar jam sekolah, membawa ke tempat perawatan kesehatan yang lebih berkualitas, dan lain-lain. Hal ini berarti biaya untuk membesarkan dan merawat anak menjadi besar. Dalam masyarakat modern jika pendapatan meningkat, maka jumlah anak yang di inginkan bahkan lebih sedikit.

Dari hasil perolehan data kuesioner dan juga pengamatan secara langsung di lapangan, didapatlah kesimpulan bahwa pendapatan memang sangat mempengaruhi tingkat fertilitas. Hal ini dikarenakan, responden yang berpenghasilan rendah tidak ingin memiliki banyak anak. Mereka beranggapan bahwa jika memiliki banyak anak maka beban hidup mereka akan bertambah sedangkan pendapatan mereka tidak ikut bertambah. Hal ini sangat kontras dengan responden yang memiliki pendapatan cukup tinggi yang ternyata lebih memungkinkan atau lebih mudah untuk fertilitas. Hal ini dikarenakan segala bentuk kebutuhannya akan mudah terpenuhi tanpa harus memikirkan banyak hal dan risiko. Semakin besar penghasilan keluarga akan berpengaruh terhadap besarnya keluarga dan pola konsumsi karena terdorong oleh tersedianya barang produk baru sehingga dampak dari 
pembangunan ekonomi juga akan merubah pandangan tentang jumlah anak yang dilahirkan. Kenaikan pendapatan akan menyebabkan harapan orang tua untuk berubah.

\section{Pengaruh Tingkat Pendidikan Terhadap Fertilitas}

Tingkat pendidikan wanita dianggap sebagai salah satu variabel yang penting dalam melihat variasi tingkat fertilitas. Karena variabel ini banyak berperan dalam perubahan status, sikap dan pandangan hidup mereka di dalam masyarakat. Pendidikan istri merupakan faktor sosial paling penting dalam analisis demografi. semakin tinggi tingkat pendidikan istri atau wanita cenderung untuk merencanakan jumlah anak yang semakin sedikit. Keadaan ini menunjukkan bahwa wanita yang telah mendapatkan pendidikan lebih baik cenderung memperbaiki kualitas anak dengan cara memperkecil jumlah anak, sehingga akan mempermudah dalam perawatannya, membimbing dan memberikan pendidikan yang lebih layak.

Kepala keluarga adalah seorang yang bertanggung jawab terhadap suatu keluarga yang dalam hal ini adalah seorang bapak Tingkat pendidikan kepala keluarga adalah jenjang pendidikan seorang pimpinan keluarga yang diukur dari jenjang pendidikan terakhir sekolahnya yaitu SD, pendidikan tingkat pertama pendidikan menengah keatas dan perguruan tinggi.

Pendidikan dianggap sebagai input dan output perubahan demografi, pendidikan yang tinggi sering kali mendorong kesadaran orang untuk tidak memiliki banyak anak. Dengan pendidikan yang tinggi seseorang cenderung memilih untuk mempunyai anak dalam jumlah kecil tetapi bermutu, dibanding dengan memiliki banyak anak tetapi tidak terurus.

Dari hasil pengukuran koefisien regensi pada tabel 9. Didapat hasil 0 (sangat rendah) hal ini mengindikasikan bahwa di Desa Laut Dendang pendidikan tidak berpengaruh terhadap tingkat fertilitas wanita PUS.

\section{Pengaruh Usia Perkawinan Pertama Terhadap Fertilitas}

Dalam masyarakat orang yang menikah memperoleh status baru, dimana status ini merupakan status sosial yang dianggap paling penting. Seperti yang diketahui bahwa pada saat seseorang menikah pada usia yang relatif lebih muda, maka masa subur atau reproduksi akan lebih panjang dalam ikatan perkawinan sehingga mempengaruhi peningkatan fertilitas.

Berdasarkan hasil perhitungan koefisien regensi didapatlah hasil -0.65092 (kuat) yang dimana dapat diambil kesimpulan bahwa usia perkawinan pertama memegang peran yang penting terhadap tingkat fertilitas wanita PUS di Desa Laut Dendang. Usia perkawinan pertama pada istri adalah rata-rata 20-25, kemudian untuk suami adalah 26-30. Responden menegaskan bahwa mereka melanjutkan pendidikan kemudian berkarir sebab mereka beranggapan bahwa keluarga mereka akan sejahtera apabila mereka menyusun dengan matang rancangan masa depan mereka. Salah satunya adalah dengan menikah disaat karir sudah baik. Sehingga keluarga yang terbentuk pun akan sempurna. Responden menjawab bahwa usia wanita saat perkawinan pertama dapat mempengaruhi risiko melahirkan. Semakin muda usia saat perkawinan pertama semakin besar risiko yang dihadapi bagi keselamatan ibu maupun anak, karena disebabkan belum matangnya rahim wanita usia muda untuk memproduksi anak atau belum siap mental dalam berumah tangga. Demikian pula sebaliknya, semakin tua usia perkawinan pertama semakin tinggi risiko yang dihadapi dalam masa kehamilan atau melahirkan. Selain itu responden menegaskan bahwa saat seseorang menikah pada usia yang relatif lebih muda, maka masa subur atau reproduksi akan lebih panjang dalam ikatan perkawinan sehingga mempengaruhi peningkatan fertilitas.

\section{Pengaruh Status pekerjaan istri Terhadap Fertilitas}

Keinginan para wanita untuk dapat meningkatkan taraf hidup dan perbaikan ekonomi serta keadilan sosial keluarga senantiasa tergambar dari upaya yang selalu mereka lakukan, misalnya dengan bekerja di bidang pertanian atau mencari nafkah untuk menambah penghasilan keluarga. Wanita pada umumnya sangat peka dengan keadaan dan permasalahan yang terjadi dalam keluarga, mereka akan menjadi penengah untuk setiap masalah yang terjadi dalam kelurga mereka juga tidak akan segan-segan untuk memasuki dunia pekerjaan yang beresiko tinggi apabila keadaan keluarga mereka mengharuskan untuk berbuat demikian. 
Berdasarkan tabel 9. Didapat hasil koefisien kontingensi -0.05300 (sedang) menunjukkan bahwa status pekerjaan wanita cukup berpengaruh terhadap tingkat fertilitas Wanita PUS di Desa Laut Dendang yang memang rata-rata tidak bekerja, mereka hanyalah Ibu Rumah Tangga biasa, yang mengurus anak dan suami. Akan tetapi ada beberapa responden yang menyatakan bahwa mereka merupakan wanita karir. Yang dimana mereka bekerja untuk memenuhi atau ikut membantu perekonomian keluarga. Wanita yang bekerja ini juga memiliki anak yang lebih dari 1. Walautpun begitu mereka mengaku tidak memiliki kesulitan yang berarti hanya karena harus merawat keluarga dan disisi lain mereka juga bekerja.

\section{Pengaruh Permintaan Anak Pada Wanita PUS Terhadap Fertilitas}

Permintaan anak pada wanita PUS menjadi factor kuat yang menentukan tingkat fertilitas di Desa Laut Dendang. Hal ini sejalan dengan didapatnya hasil koefisien regensi sebesar -0.63129 (kuat). Selain itu responden yang berusia muda menjawab bahwa mereka akan terus memiliki anak karena mereka mengganggap usia mereka masih aman untuk melahirkan. Sedangkan pada responden yang sudah berumur menjawab tidak ingin menambah anak lagi. Mereka takut akan risiko yang mungkin saja dapat terjadi dan dapat membahayakan mereka.

\section{Pengaruh Penggunaan KB Terhadap Fertilitas}

Tingkat penggunaan KB menjadi salah satu faktor penentu fertilitas di Desa Laut Dendang. Melalui table 9 didapatlah hasil koefisien regensi sebesar -0.43364 (sedang) artinya bahwa penggunaan KB ini memang berpengaruh bagi fertilitas meskipun tidak terlalu signifikan.

Melalui data yang ditemukan dilapangan didapatlah informasi bahwa rata-rata atau sebagian besar wanita di desa Laut Dendang mempunyai pengetahuan tentang KB dan mereka juga telah memakai $\mathrm{KB}$, akan tetapi sebagian lagi menjawab bahwa mereka memang sengaja untuk tidak memakai $\mathrm{KB}$, mereka ingin terus memiliki anak. Karena mereka beralasan agar umur anak-anak mereka tidak terlalu jauh dan mereka akan lebih mudah dalam mengasuh dan membersarkan anak mereka.

\section{KESIMPULAN DAN SARAN}

Berdasarkan hasil penelitian yang dilakukan di Desa Laut Dendang, maka didapatlah kesimpulannya bahwa:

1. Pendapatan sangat mempengaruhi tingkat fertilitas. Hal ini dikarenakan semakin tinggi pendapatan maka akan semakin rendah tingkat fertilitas.

2. Pendidikan tidak memiliki pengaruh terhadap fertilitas di Desa Laut Dendang.

3. Usia nikah pertama menjadi salah satu faktor kuat yang mempengaruhi fertilitas di Desa Laut Dendang karena semakin muda usia perkawinan pertama semakin besar risiko yang dihadapi bagi keselamatan ibu maupun anak, demikian pula sebaliknya, semakin tua usia perkawinan pertama semakin tinggi risiko yang dihadapi dalam masa kehamilan atau melahirkan.

4. Pengaruh status pekerjaan istri terhadap fertilitas yang dimana pada umumnya sangat peka dengan keadaan dan permasalahan yang terjadi dalam keluarga, mereka akan menjadi penengah untuk setiap masalah yang terjadi dalam kelurga mereka juga tidak akan segan-segan untuk memasuki dunia pekerjaan yang beresiko tinggi apabila keadaan keluarga mereka mengharuskan untuk berbuat demikian. yang menyatakan bahwa mereka merupakan wanita karir. Memang ada mereka (istri) bekerja untuk memenuhi atau ikut membantu perekonomian keluarga. Wanita yang bekerja ini juga memiliki anak yang lebih dari 1 .

5. Pengaruh permintaan anak pada wanita PUS tinggi terhadap fertilitas, dimana istri yang masih berumur muda ingin memiliki anak karena mereka mengganggap usianya masih aman untuk melahirkan. Sedangkan pada istri yang sudah tua tidak ingin menambah anak lagi karena takut akan risiko yang mungkin saja dapat terjadi dan dapat membahayakan.

6. Penggunaan KB cukup berpengaruh terhadap fertilitas di Desa Laut Dendang.

Berdasarkan data yang diperoleh dari penelitian ini maka berikut adalah saran yang dapat diberikan:

1. Untuk wanita muda di Desa Laut Dendang, agar lebih meningkatkan 
pendidikan yang merupakan salah satu cara menurunkan tingkat fertilitas.

2. Untuk mengurangi fertilitas itu sendiri kiranya pemerintah mengadakan sosialisasi yang lebih mendalam tentang $\mathrm{KB}$.

3. Perlu dilakukan penelitian yang lebih lanjut terkait misalnya seperti alat kontrasepsi apa yang paling aman digunakan untuk mengurangi fertilitas.

\section{DAFTAR PUSTAKA}

BKKBN, 2015. Rencana Strategis Badan Kependudukan dan Keluarga Berencana Nasional Tahun 2015 2019.

Desa Laut Dendang, 2016. Data Statistik Desa Laut Dedang Tahun 2016. Tidak dipublikasi

Hatmaji, Sri. 2004. Fertilitas Dalam Dasardasar Demografi. Jakarta LDFFE.UI

Iswarati. 2009. Proximate Determinant Fertilitas di Indonesia (Analisis Lanjut SDKI 2007). Jakarta: BKKBN.

Mantra, Ida Bagoes. 2012. Demografi Umum. Pustaka Pelajar, Yogyakarta.

Saleh, M. 2003. Pengaruh Jenis Pekerjaan Dan Waktu Kerja Wanita Terhadap Struktur Sosial Ekonomi Keluarga Serta Fertilitas Di Kabupaten Jember Jawa Timur. Tidak dipublikasikan. Pasca sarjana: Airlangga (Disertasi).

Singarimbun, Masri dan Sofian Effendi. 2008. Metode Penelitian Survai. Jakarta: Pustaka LP3ES Indonesia.

Sukarno, 2010. Pengaruh Faktor Sosial Ekonomi Terhadap Fertilitas dan Umur Kawin Pertama. Jurnal Pusat Penelitian dan Pengembangan KB dan KS. BKKBN

Undang-Undang Republik Indonesia Nomor 1 Tahun 1974 tentang Perkawinan.

UMK Deli Serdang, 2018. Kriteria Upah Minimun Kabupaten Deli Serdang 